\title{
Response of Cowpea (Vigna unguiculata) to Inorganic and Biofertilizers
}

\author{
N.K. Kalegore, M. A. Gavhane*, S. A. Bhusari and S. V. Kasle and R. S. Dhamane
}

Agronomy Section, College of Agriculture, VNMKV, Latur, M.S. (431 512), India

\section{Corresponding Author}

M. A. Gavhane

e-mail: madhavgavhane55@gmail.com

\author{
Article History \\ Article ID: IJEP0265 \\ Received in $25^{\text {th }}$ July, 2018 \\ Received in revised form $13^{\text {th }}$ September, 2018 \\ Accepted in final form $28^{\text {th }}$ September, 2018
}

\begin{abstract}
A field experiment was conducted to study the Effect of inorganic and biofertilizers on growth and yield of cowpeaat Agronomy section, College of Agriculture, VNMKV, Latur, India. The experimental field was levelled and well drained. The soil was clayey in texture, moderate in nitrogen $\left(216 \mathrm{~kg} \mathrm{ha}^{-1}\right)$, medium in phosphorous $\left(16.54 \mathrm{~kg} \mathrm{ha}^{-1}\right)$, high in potash (465 kg ha-1) and moderate alkaline in nature (8.02 $\left.\mathrm{pH}\right)$. The experiment was laid out in a factorial randomised block design. Each experimental unit was replicated three times. The gross and net plot size of each experimental unit was $5.4 \times 4.2$ and $4.8 \times 3.6 \mathrm{~m}^{2}$ respectively. There were nine treatment combinations of levels each of RDF and bio fertilizer viz. 75\% RDF, 100\% RDF, per cent RDF and Seed inoculation of PSB, Seed inoculation of rhizobium, dual seed inoculation of PSB+Rhizobium. Application of $125 \%$ RDF was recorded significantly higher growth and yield contributing characters viz. plant height $(92.8 \mathrm{~cm})$, no. of branches plant ${ }^{-1}(8.7)$ no. of functional leaves plant ${ }^{-1}(29.6)$, dry matter plant ${ }^{-1}(23.6 \mathrm{~g})$ and no.of seeds plant ${ }^{-1}(66.1)$, no of pods plant ${ }^{-1}(8.6)$ pod yield plant ${ }^{-1}(7.98 \mathrm{~g})$, seed yield kg ha- ${ }^{-1}(1564)$, straw yield $\left(3881 \mathrm{~kg} \mathrm{ha}^{-1}\right)$ and seed index (8.7 g) respectively over the application of $75 \%$ RDF. Dual inoculation of PSB+Rhizobium culture was found superior than alone PSB treatment in respect of growth and yield parameters
\end{abstract}

Keywords: Bio fertilizer, RDF, PSB, rhizobium, pH, phosphorous, fertilizer

\section{Introduction}

Cowpea (Vigna unguiculata L.) is of immense importance multipurpose grain legume. The green pods of cowpea are used as vegetables. In addition to grain, it is also grown for its nutritious fodder under favourable conditions. It contains protein $23.4 \%, 1.8 \%$ fat and $60.3 \% \mathrm{CHO}$ also rich in source of ca and Fe. It is grown as green manure crop for soil improvement. Cowpea is called as vegetable meat due to high amount of protein with better biological value on dry weight basis. Increasing fertilizer prices and high requirement of nutrients differthe farmers from using the recommended doses of inorganic fertilizers. However pulses can harvest more than synthetically produced nitrogen from atmosphere saving huge quantity costlier energy. The bacterial culture inoculated to seeds for increasing pulse crop yield nowdays is becoming standard practice. Seed inoculation has assumed greater importance in the improvement of crop production, specially of pulse crops. Special attention must be given to the bacterial inoculation. It is generally, done by inoculation seeds to be sown with effective strain of rhizobia for increasing the yield of crop and nitrogen content of the soil. India is the largest producer and consumer of pulses in the world accounting for about $29 \%$ of the world area and $19 \%$ of the worldproduction. At present the total area under pulses is 21.64 mha with production of $11.93 \mathrm{mt}$. Among grain legumes, the green pods of cowpea are used as vegetables. In addition to grain, it is also grown for its also grown for its nutritious fodder. Cowpea is grown as catch crop, mulch crop, intercrop, mixed crop, and green crop. It has ability to fix atmospheric nitrogen in soil at the rate of $56 \mathrm{~kg} \mathrm{ha}^{-1}$ in association with symbiotic bacteria under favourable condition.

\section{Materials and Methods}

The field experimentwas conducted during kharif season of 2011 at the Experimental Farm, Agronomy Section, College of Agriculture VNMKV, Latur. (M.S), India to study the effect of inorganic and biofertilizers on growth, yield and quality of cowpea (konkan sadabhar). The experiment was laid in Fractional Randomized Block Design (FRBD) with nine treatment combinations of three levels RDF and bio fertilizer and replicated thrice. To find out the suitable combination of $\mathrm{N}$ and $\mathrm{P}$ with biofertilizers and to assess the effect of inorganic and biofertilizers on protein content of cowpea. The gross and net plot size of each experimental unit was $5.4 \times 4.2 \mathrm{~m}^{2}$ and $4.8 \times 3.6 \mathrm{~m}^{2}$ respectively. The soil of the experimental plot was deep black in colour with good drainage and levelled topography with clayey in texture, moderate in nitrogen (216 kg ha-1), medium in phosphorous (16.54 kg ha-1), high 
in potash (465 $\left.\mathrm{kg} \mathrm{ha}^{-1}\right)$ and moderate alkaline in nature(8.02 $\mathrm{pH})$. The crop was sown by dibbling with 2-3 seeds hill ${ }^{-1}$ at a distance of $300 \mathrm{~cm}^{2}$ at about $2.5 \mathrm{~cm}$ depth. Sowing of seeds was done on $9^{\text {th }}$ July, 2011. The recommended dose of fertilizer(25:50:00 NPK kg ha-1) was applied through DAP and Urea.The three fertilizer levels were 75, 100 and 125\% RDF and three biofertilizers treatments were PSB, Rhizobium and PSB+Rhizobium.

\section{Results and Discussion}

\subsection{Effect of different levels of RDF on Growth and Yield of cowpea}

The growth and yield parameters of cowpea were significantly influenced by different levels of fertilizers and bio fertilizers
(Table 1). The maximum plant height $(92.8 \mathrm{~cm})$, no. of functional leaves plant ${ }^{-1}(29.6)$, no. of pods plant ${ }^{-1}$ (8.6), seed yield (1564 kg ha-1), straw yield (3881 kg ha-1) were recorded due to the application of fertilizer levels $125 \% \operatorname{RDF}\left(F_{3}\right)$ and significantly superior than $75 \% \operatorname{RDF}\left(F_{1}\right)$ but satisfactory at par with the application of 100 per cent $\operatorname{RDF}\left(F_{2}\right)$. The higherno. of branches plant ${ }^{-1}(8.7)$, no. of seeds plant ${ }^{-1}$ (66.1) and pod yield plant ${ }^{-1}(7.98 \mathrm{~g})$ was recorded due to the application of fertilizer levels $125 \% \operatorname{RDF}\left(F_{3}\right)$ and significantly superior over the treatments 100 per cent RDF $\left(F_{2}\right)$ and $75 \% \operatorname{RDF}\left(F_{1}\right)$. The higher dry matter production plant ${ }^{-1}(23.6 \mathrm{~g})$ and seed index (8.7) was recorded due to the application of $125 \% \operatorname{RDF}\left(F_{3}\right)$ but did not found significantly superior over the treatments $100 \% \operatorname{RDF}\left(F^{2}\right)$ and $75 \% \operatorname{RDF}\left(F_{1}\right)$.

\begin{tabular}{|c|c|c|c|c|c|c|c|c|c|c|}
\hline Treatments & $\begin{array}{l}\text { Plant } \\
\text { height } \\
(\mathrm{cm})\end{array}$ & $\begin{array}{l}\text { No. of } \\
\text { branches } \\
\text { plant }^{-1}\end{array}$ & $\begin{array}{c}\text { No. of } \\
\text { functional } \\
\text { leaves } \\
\text { plant }^{-1}\end{array}$ & $\begin{array}{l}\text { Dry } \\
\text { matter } \\
\text { plant }^{-1} \\
\text { (g) }\end{array}$ & $\begin{array}{l}\text { No. of } \\
\text { seeds } \\
\text { plant }^{-1}\end{array}$ & $\begin{array}{l}\text { No. of } \\
\text { pods } \\
\text { plant }^{-1}\end{array}$ & $\begin{array}{l}\text { Pod } \\
\text { yield } \\
\text { plant }^{-1} \\
\text { (g) }\end{array}$ & $\begin{array}{c}\text { Seed } \\
\text { yield } \\
\text { kg ha-1 }^{-1}\end{array}$ & $\begin{array}{l}\text { Straw } \\
\text { yield } \\
\text { kg ha-1 }^{-1}\end{array}$ & $\begin{array}{c}\text { Seed } \\
\text { index } \\
\text { (g) }\end{array}$ \\
\hline \multicolumn{11}{|l|}{ Fertilizer levels (F) } \\
\hline $\mathrm{F}_{1}: 75 \% \mathrm{RDF}$ & 79.3 & 6.3 & 24.5 & 21.1 & 47.2 & 7.7 & 5.96 & 1222 & 3306 & 8.6 \\
\hline $\mathrm{F}_{2}: 100 \% \mathrm{RDF}$ & 85.3 & 7.7 & 27.2 & 22.4 & 58.3 & 7.9 & 6.96 & 1456 & 3641 & 8.7 \\
\hline $\mathrm{F}_{3}: 125 \% \mathrm{RDF}$ & 92.8 & 8.7 & 29.6 & 23.6 & 66.1 & 8.6 & 7.98 & 1564 & 3881 & 8.7 \\
\hline SEm \pm & 2.78 & 0.26 & 0.8 & 0.80 & 1.7 & 0.24 & 0.27 & 53 & 160 & 0.13 \\
\hline $\mathrm{CD}(p=0.05)$ & 8.34 & 0.79 & 2.5 & NS & 5.3 & 0.72 & 0.81 & 158 & 480 & NS \\
\hline \multicolumn{11}{|l|}{ Biofertilizers (B) } \\
\hline $\mathrm{B}_{1}: \mathrm{PSB}$ & 78.6 & 7.1 & 25.6 & 21.7 & 50.1 & 7.4 & 6.33 & 1305 & 3468 & 8.6 \\
\hline $\mathrm{B}_{2}:$ Rhizobium & 85.5 & 7.1 & 26.5 & 22.5 & 53.1 & 8.3 & 7.06 & 1355 & 3634 & 8.7 \\
\hline $\mathrm{B}_{3}:$ PSB+Rhizobium & 93.4 & 8.5 & 29.3 & 24.8 & 59.9 & 08.4 & 7.51 & 1581 & 3725 & 8.7 \\
\hline SEm \pm & 2.78 & 0.26 & 0.8 & 0.80 & 1.7 & 0.24 & 0.27 & 53 & 160 & 0.13 \\
\hline $\mathrm{CD}(p=0.05)$ & 8.34 & 0.79 & 2.5 & NS & 5.3 & 0.72 & 0.81 & 158 & 480 & NS \\
\hline \multicolumn{11}{|l|}{ Interaction $\mathrm{F} \times \mathrm{B}$} \\
\hline SEm \pm & 8.34 & 0.45 & 1.44 & 1.32 & 3.00 & 0.41 & 0.47 & 91 & 88.06 & 0.22 \\
\hline $\operatorname{CD}(p=0.05)$ & NS & NS & NS & NS & NS & NS & NS & NS & NS & NS \\
\hline
\end{tabular}

3.2. Effect of different levels of Biofertilizers on growth and yield of cowpea

The maximum plant height $(93.4 \mathrm{~cm})$, no of pods plant ${ }^{-1}$ (8.4) and pod yield plant ${ }^{-1}$ (7.5 g) was recorded due to the application of PSB+Rhizobium $\left(B_{3}\right)$ and satisfactory at par with the application of rhizobium $\left(B_{2}\right)$ and found significantly superior over the treatment PSB $\left(B_{1}\right)$. The higher straw yield (3725 kg ha-1) was recorded due to the application of PSB+ Rhizobium $\left(B_{3}\right)$ and significantly at par with the treatments rhizobium $\left(B_{2}\right)$ and PSB $\left(B_{1}\right)$. The maximum no. branches plant $^{-1}(8.5)$, no. of functional leaves plant ${ }^{-1}(29.3)$, no. of seeds plant $^{-1}(59.9)$ and seed yield $\left(1581 \mathrm{~kg} \mathrm{ha}^{-1}\right)$ was recorded due to the application of PSB + Rhizobium $\left(B_{3}\right)$ and significantly superior over the treatments rhizobium $\left(B_{2}\right)$ and PSB $\left(B_{1}\right)$. The maximum dry matter plant ${ }^{-1}(24.8 \mathrm{~g})$ and seed index (8.7 g) was recorded due to the application of PSB + Rhizobium $\left(B_{3}\right)$ but did not found significantly superior over the treatments rhizobium $\left(B_{2}\right)$ and PSB $\left(B_{1}\right)$. The interaction fertilizer levels and biofertilizers was did not found significant in case of all growth and yield attributing characters. The combined effect of PSB and rhizobium culture increased phosphorous availability and rhizobiumprovides the availability of atmospheric $\mathrm{N}$ for better growth of the crop.

\subsection{Economics of cowpea influenced by different treatments}

Data presented in Table 2. Revealed that the highest gross monetary returns ( $₹ 50801 \mathrm{ha}^{-1}$ ) and net monentry returns 
Table 2: Economics of cowpea as influenced by different treatments

\begin{tabular}{|c|c|c|c|}
\hline Fertilizer levels (F) & $\begin{array}{c}\text { GMR } \\
\left(₹ h^{-1}\right)\end{array}$ & $\begin{array}{c}\text { NMR } \\
\left(₹ h^{-1}\right)\end{array}$ & $\begin{array}{c}\text { B:C } \\
\text { Ratio }\end{array}$ \\
\hline \multicolumn{4}{|l|}{ Fertilizer levels (F) } \\
\hline $\mathrm{F}_{1}: 75 \% \mathrm{RDF}$ & 39966 & 22125 & 2.2 \\
\hline $\mathrm{F}_{2}: 100 \% \mathrm{RDF}$ & 47321 & 28836 & 2.6 \\
\hline $\mathrm{F}_{3}: 125 \% \mathrm{RDF}$ & 50801 & 31672 & 2.6 \\
\hline SEm \pm & 1717 & 1717 & - \\
\hline $\mathrm{CD}(p=0.05)$ & 5151 & 5151 & - \\
\hline \multicolumn{4}{|l|}{ Biofertilizers (B) } \\
\hline $\mathrm{B}_{1}: \mathrm{PSB}$ & 42618 & 24108 & 2.3 \\
\hline $\mathrm{B}_{2}:$ Rhizobium & 44284 & 25709 & 2.4 \\
\hline $\mathrm{B}_{3}:$ PSB+Rhizobium & 51155 & 32555 & 2.7 \\
\hline SEm \pm & 1717 & 1717 & - \\
\hline $\operatorname{CD}(p=0.05)$ & 5151 & 5151 & - \\
\hline \multicolumn{4}{|l|}{ Interaction $\mathrm{F} \times \mathrm{B}$} \\
\hline SEm \pm & 3312 & 3312 & - \\
\hline $\operatorname{CD}(p=0.05)$ & NS & NS & _ \\
\hline
\end{tabular}

( $₹ 28836 \mathrm{ha}^{-1}$ ) was obtained due to the application of fertilizer levels $125 \% \operatorname{RDF}\left(F_{3}\right)$ and significantly superior than $75 \%$ $\operatorname{RDF}\left(\mathrm{F}^{1}\right)$ but satisfactory at par with the application of 100 per cent RDF $\left(F_{2}\right)$. The highest B:C ratio (2.6) was recorded due to the application of fertilizer levels 125\% RDF $\left(F_{3}\right)$. The application of biofertilizers $\mathrm{PSB}+$ Rhizobium $\left(\mathrm{B}_{3}\right)$ recorded highest gross monetary returns ( $₹ 51155 \mathrm{ha}^{-1}$ ) and which is at par with the application of rhizobium $\left(B_{2}\right)$ and PSB $\left(B_{1}\right)$. The highest net monetary returns ( $₹ 18600 \mathrm{ha}^{-1}$ ) and benefit cost ratio was recorded due to the application of biofertilizers PSB+Rhizobium $\left(B_{3}\right)$.

\section{Conclusion}

Application of $125 \%$ RDF recorded higher growth and yield as well as economic returns but it was found at par with 100 per cent RDF. The Application of 100\% RDF (25:50:00 NPK ha-1) along with combined seed treatment of PSB and rhizobium was found beneficial than alone seed treatment of PSB.

\section{References}

Anilkumarsingh, P.N., Tripathi and Singh, R., 2007. Effect of
Rhizobium inoculation, nitrogen and phosphorous levels on growth, yield and quality of kharif cowpea. Crop Research 33(1, 2 \& 3), 71-78.

Dekhane, S.S., Khafi, H.R., Raj, A.D., Parmar, R.M., 2011. Effect of bio fertilizer and fertiolity levels on yield, protein content and nutrient uptake by cowpea., Advance in plant sciences 14(20) 571-575.

Dhage, S.J., Kanchhave, K.G., 2007. Effect of dual inoculation of rhizobium and PSB on yield contributing characters and seed yields of soybean. Journal of Maharashtra Agriculture University 33(2), 209-211

Kushwaha, H.S., 2007. Reasponse of chickpea to bio fertilizes, nitrogen and phosphorous fertilization under rainfed environment. Journal of food legumes 20(2), 114-118.

Meera, V., Menon, D., Reddy, V., Pramila, P., Krishnamurthy, J., 2010. Seed production in vegetable cowpea ( vigna unguiculata) under integrated nutrient management. Legume Research 33(4), 299-301.

Oliveria, A.P., Bruno, E.V., Alvas and Pereira, E.L., 2001. Yield and quality of cowpea (vigna unguiculata L.) Walp seeds in functions of levels and application of nitrogen. Bevista Brazileira de Semente 23(2), 215-221.

Sangkakar, U.R., Frener, M., Nosberger, J., 2001. Influence of soil moisture and fertilizer potassium on the vegetative growth of mungbean (Vigna radiate L.) and cowpea (Vigna unguiculata L.) Journal of Agronomy and crop science 186(2), 73-74.

Sawargaokar, G.L., Sawargaokar, S.L., Bhamare, V.K., . Shinde, S. A., Borgaokar, S.B., 2006. Optimization of nitrogen and phosphorous fertilization for frenchbean during winter in Marathwada region. Crop Protection and Production., 2(2), 56-58.

Shripriya, B., Deotale, R.D., hatmode, C.N., Titare, P.S., Thorat, A.W., 2005. Effect of biofertilizers (pressmud, rhizobium and PSB) and nutrients (NPK) on Morpho-physiological parameters of greengram. Journal of soil and crop 15(2), 442-444.

Sunneta, C.H., Venkatesware, B., Subajah, G., Peased, P.R.K., 2005. Response of fodder cowpea to lower of seed inoculation and phosphorus. The Andhra Agriculture Journal 51(3\&4), 528-530. 